\title{
Approaching Clients With Multiple Sclerosis in Social Services
}

Petr Černý

Multiple sclerosis (further also MS) is a neurological autoimmune disease affecting the central nervous system. In its incurable phase it is already a chronic disease. In social services persons suffering of MS are perceived first as chronically ill and in the more progressive stage of the disease as physically disabled due to their immobility. Due to the chronicity of the disease the patients often undergo physiological, psychological, social, and spiritual changes. They become more sensitive, and thus more vulnerable. That is why they need adequate relational support to saturate all their needs, so that the quality and dignity of their life is maintained.

With respect to the quality of approaching MS clients in social services a number of questions arise, e.g. Whether the requirement of maintaining the quality of life and respect to these persons is met in practice. This paper therefore focuses on wrong attitudes of caregivers, which are specific to such clients. Against the backdrop of professional literature and personal questioning of such patients in various social services the paper presents the most common forms of problematic attitudes. By engaging a holistic view of the human being I also want to point out various aspects which need to be respected in order to appreciate the patients in their complexity.

\section{Multiple sclerosis}

Every disease, especially if it is incurable, affects the human being at all levels: biological, psychological, social, and spiritual. Multiple sclerosis is an inflammatory autoimmune disease of the central nervous system, i.e., in the celebro-spinal area, which causes damage or complete loss of nerve sheath (myelin) and process of nerve fibre (axon). Loss of axons causes permanent invalidity in MS patients. ${ }^{1}$ According to latest data from 2008-2009 the epidemiological occurrence of multiple sclerosis in the Czech Republic was 160/100 000 inhabitants. ${ }^{2}$ It most commonly breaks out between 20 and 40 years of age. ${ }^{3}$ The disease can be diagnosed by means of magnetic resonance. In the chronic form of the disease symptoms can be relieved by early treatment and rehabilitation, but the disease cannot be cured. The most marked manifestation of the disease is gradual loss of mobility of the locomotive organs, which is why patients gradually become physically disabled. The disease may manifest itself differently in different patients depending on the location of nervous tissue damage: by the already mentioned gradual immobility of the locomotive organs, tripping ("dragging one's feet"), balance disorders, spasms, incontrollable trembling, increased sensitivity, inhibited articulation, vision disorders, incontinency, intestine disorders, thermoregulation disorders, pathological fatigue, greater mood fluctuation, and others. ${ }^{4}$ In unfavorable conditions, such as emotional stress or

1 Cf. Eva HAVRDOVÁ, Roztroušená skleróza, 2. ed., Praha: Maxdorf, 2009, p. 8.

2 Cf. Marta VACHOVÁ, Epidemiologie roztroušené sklerózy a neuromyelitis optica, in: Roztroušená skleróza, ed. Eva HAVRDOVÁ, Praha: Mladá fronta, 2013, p. 33.

3 Ibid., p. 22.

4 Cf. Eva HAVRDOVÁ, Roztroušená skleróza, pp. 23-26; Eva HAVRDOVÁ, Roztroušená skleróza, Česká a slovenská neurologie a neurochirurgie 2/2008, pp. 123-124. 
bad weather, the symptoms intensify. Patients must cope with a great disproportion in their life, since while they progressively lose mobility, their intellect is normally fully preserved, and thus they are fully aware of their increasing helplessness and dependence on others. Due to decreased self-sufficiency MS patients are more dependent on the care of relatives or professional caregivers, they have greater need of human closeness, understanding and support. When they learn their diagnosis and prognosis, they are in shock, they often experience panic, fear, and hopelessness. They become aware that their existence is threatened, their inner integrity is violated, they experience fear of death. To the extent each of them is capable, they are forced by their unfavorable situation to accept the disease, to search for a new identity, to take a whole new attitude to the meaning and values of life. ${ }^{5}$ If that does not happen, feelings of helplessness and insecurity lead patients without necessary psychosocial support either to withdraw into themselves and suffer, or to manifest aggression. ${ }^{6}$ That is why MS patients so often struggle with depression. ${ }^{7}$ Without relational support they can enter a limit situation. ${ }^{8}$ When they have eventually accepted their new identity, they focus more on their close ones and strive to at least keep up their current state of health. ${ }^{9}$

\section{Social aspects in MS patients}

In view of our aim it is important to describe not only the characteristics of the disease but also the social aspects of the patients, since it will help us clarify the needs of clients with multiple sclerosis in social services and adequate approach to them. Persons with such health disability and related symptoms are socially stigmatized, ${ }^{10}$ they suffer from social exclusion. They become more sensitive, and thereby more vulnerable. Due to the dynamics of psychosocial changes MS patients need not only pharmacological treatment but also psychotherapeutic support early on. ${ }^{11}$ Based on questionnaire survey results, M. Vachová concludes that the quality of such patients' personal as well as professional life decreases. ${ }^{12}$ Adequate approach should thus be assumed in caring for them.

As a result of the disease, attitude and role changes occur both in the patient and his nearest. All interested parties must gradually learn to cope with the change and adapt to the new situation. ${ }^{13}$ As with every grave disease without the prospect of cure, persons with multiple sclerosis go through crisis stages as described by E. Kübler-Ross (denial, anger, bargaining, depression, acceptance). ${ }^{14}$ Due to the decrease in mobility and self-sufficiency they often lose their jobs and favorite leisure activities, whereby they enter social isolation. In this social "drop" patients lose some "friends", while other relationships are strengthened and real new friendships arise. Due to loss of customary social ties, insecurity with respect to the future and fear

\footnotetext{
5 Cf. Eva HAVRDOVÁ - Martina HOSKOVCOVÁ - Jana DUŠÁNKOVÁ - Eva KRASULOVÁ - Martina PURŠOVÁ, Je roztroušená skleróza váš problém?, 2. ed., Praha: Unie Roska - Česká RS společnost, 2006, p. 149.

6 Cf. ibid.

7 Cf. Eva HAVRDOVÁ, Roztroušená skleróza, pp. 23-26; Eva HAVRDOVÁ, Roztroušená skleróza, p. 124.

8 SECOND VATICAN COUNCIL, constitution Lumen gentium, 16.

9 Based on the results of my own questionnaire survey of 120 multiple sclerosis patients in the Czech Republic aimed at determining the approach such patients expect in the environment of social services, 2012.

10 Cf. Josef SLOWÍK, Komunikace s lidmi s postižením, Praha: Portál, 2010, pp. 18 and 25.

11 Cf. Marta VACHOVÁ, Sociální aspekty roztroušené sklerózy, in: Roztroušená skleróza, ed. Eva HAVRDOVÁ, Praha: Mladá fronta, 2013, p. 453.

12 Cf. ibid., p. 454.

13 So far cf. Eva HAVRDOVÁ - Martina HOSKOVCOVÁ - Jana DUŠÁNKOVÁ - Eva KRASULOVÁ - Martina PURŠOVÁ, Je roztroušená skleróza váš problém?, p. 149.

14 Cf. Elisabeth KÜBLER-ROSSOVÁ, O smrti a umírání, Turnov: Arica, 1993, pp. 35-120.
} 
of progression patients without necessary psychosocial support can become desperate and acquire behavioral disorders. ${ }^{15}$

Unfortunately, the gravest consequence of chronic disease is deterioration of partner relationships, which is much more common as compared to healthy population. ${ }^{16}$ For cases when marriage is successfully maintained J. Křivohlavý states with reference to various studies that although the mutual relationship of the spouses improved in a number of cases (with respect to social distance), the measure of satisfaction in marriage did not increase - rather the contrary..$^{17}$ In the intimate life of partners there occurs impaired perception of one's own sexual attractiveness due to mobility, sensitivity and sexual functions disorders. ${ }^{18}$

\section{Ethically problematic forms of approaching MS patients in social services}

In order to grasp the issue properly I will first clarify the concept of "approach" in the context of this paper. I use the term to signify the attitude of caregivers in caring for and communicating with MS patients; the context relevant to this paper are social services.

The quality of approaching clients with MS is determined by the momentary psychosocial condition of the patients (e.g. in connection with psychological changes occurring while learning to cope with the disease as described by E. Kübler-Ross - see above) as well as by the momentary disposition of the caregivers. Despite the expected professional approach, mental and physical fatigue of the caregivers also plays a part in caring for such demanding clients. ${ }^{19}$ Another factor that may affect the quality of the caregivers' approach to their clients is their conviction that they are insufficiently paid for their work. ${ }^{20}$

The facts we have outlined in the preceding chapters on their own suggest the need to approach these people in a specific manner, especially in the "impersonal" environment of social services. The literature on the topic and my own questioning of clients has shown that in practice the requirements of a specific approach are not always met, and one may even encounter problematic approaches. Of the wrong attitudes of caregivers in social services mentioned in the literature ${ }^{21}$ and on the MPSV ČR web site ${ }^{22}$ I deal only with those problematic attitudes personally encountered by multiple sclerosis clients.

The list of ethically problematic approaches below summarizes the results of my records of the experience of clients with MS in social services in various parts of the Czech Republic in 2011-2013. ${ }^{23}$ The most commonly occurring problematic approach by professional caregiv-

15 Cf. Marta VACHOVÁ, Sociální aspekty roztroušené sklerózy, p. 454.

16 Cf. ibid.

17 Cf. Jaro KŘIVOHLAVÝ, Psychologie nemoci, Praha: Grada Publishing, 2002, p. 133.

18 Cf. Tomáš DRÁBEK, Partnerský a sexuální život osob se zdravotním postižením, Praha: Svaz tělesně postižených v České republice, 2013, pp. 61 and 68 .

19 Cf. Kenneth I. PAKENHAM, Application of a stress and coping model to caregiving in multiple sclerosis, Psychology, Health E Medicine 6/2001, pp. 13-27.

20 From personal experience of P. Černý in social services for MS clients.

21 Cf. Marie VÁGNEROVÁ, Psychopatologie pro pomáhající profese, 4. ed., Praha: Portál, 2008, pp. 189-190; Josef SLOWÍK, Komunikace s lidmi s postižením, pp. 17-18.

22 (C) MPSV ČR, Zavádění standardo̊ kvality sociálních služeb do praxe - průvodce poskytovatele (on-line), at http://www.mpsv.cz/files/ clanky/5964/pruvodce.pdf, retrieved November 30, 2013.

23 This is a summary of the results of my survey of multiple sclerosis patients in the Czech Republic, realized 2011-2013, aimed at determining ethically problematic approaches of caregivers in social services. 


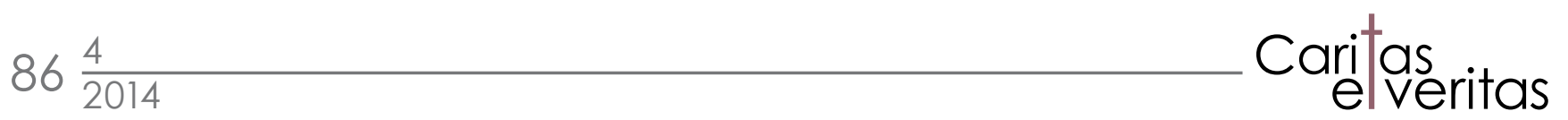

ers has turned out to be so-called "infantilizing" (using diminutives when addressing clients: e.g. "Johnny", "Lizzy"; when doing hygiene: "handie", "footie"; or when serving food). In addressing and providing care diminutive expressions inadequate to the dignity of an adult human being are used, which some clients perceive as humiliating. The caregivers adopt an overtly maternal attitude to the patients and sometimes provide more care than necessary, which suppresses the patients' own, though minimal autonomy. It is probably due to a certain "excessive" compassion of the caregiver with the MS patient, as well as greater focus on the physical immobility, to the detriment of perceiving the client as an adult with a preserved intellect. Although the patients are often happy if the caregivers accept familiar first-name terms, this is more likely to result in being treated as children. My survey has shown that those who remain on distant, family-name terms with the caregivers do not encounter this problematic approach.

Another problematic approach is "disabling", i.e., when caregivers deal with clients as not equal dialogue partners, as if they were inferior or not sui iuris, or the caregivers consider themselves to be so expert in the providing that they refuse to listen to the clients or agree on an optimal procedure with them. Unfortunately, some caregivers interpret the immobility of MS patients as incapacity to decide for themselves, which is a great mistake. Despite their dependence and impaired communication the intellect of MS patients is not normally affected. In the social services the opposite problem also occurs, when clients (mostly women) ask to be served by the caregivers although they are capable of the relevant actions themselves. In such cases it is proper for the caregivers to act assertively and not let themselves be manipulated to the detriment of supporting the clients' autonomy.

"Refusing attention" occurs especially in cases when the client suddenly needs to go to the toilet and asks the caregiver for help, but she does not assess that as urgent and continues in a different activity. Caregivers also sometimes pay insufficient attention when adjusting the clients' bed, when they sometimes do not ask if this or that position suits the patient. Due to fatigue caregivers sometimes inappropriately tell clients that they are tired, their back aches or that their shift will soon be over. On the other hand, some clients demand overt attention in not very grave matters. The caregivers then employ refusing attention as a preventive measure to protect themselves from manipulation. Sometimes clients are upset that the caregivers have so many things to do that they cannot immediately satisfy their wishes, e.g. help them change position, put them in bed, etc. In case of a more serious need, such as setting on a toilet, the caregivers grant it, but sometimes make unsuitable comments (e.g., "now she has remembered"). Some caregivers refuse to communicate with clients while providing care.

MS patients do not take well when caregivers are in a hurry, which results in "not respecting speed". Such caused stress may cause problems in communication, especially with clients who find it more difficult to express themselves or are hard of hearing.

The problem of "labelling" occurs when caregivers signify a client according to her behavior or disability with a term which is then used to refer to her (e.g. "stretcher"), or refer to the patient by her diagnosis, or in case of different ethnic background use an abusive name. In such situations so-called "stigmatization" of clients occurs in the prejudiced behavior of the caregivers, which is due to their aversion for or dislike of the patient who smells due to excessive perspiration or incontinency.

When dealing with the family in the client's presence there is the risk of "ignoring" the patient, e.g. by speaking about her without her, especially when the client cannot articulately, and 
therefore intelligibly, speak of her condition. Another kind of ignoring may occur when the caregivers refuse to regularly check the ward to see if everybody is fine. In case of an accident the clients would be unable to help themselves in the absence of another person. A certain kind of ignoring on the part of the caregiver are situations when clients are involuntarily "flooded" with monologues narrating the personal life of the caregiver. Mentions of social activities (shopping, housework, entertainment, dancing, etc.) can make the immobile clients especially sorrowful. Another kind of ignoring the patient may be lack of interest in her satisfaction with how the position of the bed has been positioned or with another act of care. When doing hygiene in the client's room there is a risk of a certain kind of ignoring the patient's privacy. It is therefore ethically more acceptable to prepare suitable environment before the act itself - i.e., by excluding the presence of other persons and closing the door.

In exceptional cases some clients may provoke certain concealed or patent mockery on the part of the caregivers. This may happen with MS patients whose articulation is impaired or who distinctively attract the caregivers' attention. Not all clients can take the peculiar reactions of the caregivers well. However, the surveyed multiple sclerosis patients agreed that compared to hospital stays they have experienced ethically problematic approach in social services rather exceptionally.

\section{Approaching MS patients in a way that appraises the dignity of the patient in her entirety}

Having introduced the disease, its social impact, as well as the ethically problematic forms of approaching such clients in social services established by research, there now arises space to ask what the practice ought to be like, what requirements there are for approaching such specific clients in social services and what ideas might be inspiring. It is definitely important to perceive the ill person in her entirety, as a bio-psycho-socio-spiritual being. ${ }^{24}$ Having outlined the physical and social issues, in what follows we will therefore also touch on the psychological and theological dimension of a human being with multiple sclerosis. In this way the patient can be appraised more objectively in her needs as well as her transcendent value.

Even in disease, a human being is first of all a person, who despite her disability does not lose her natural dignity, deserves respect, protection, and sympathy. Multiple sclerosis patients struggle with vulnerability, ${ }^{25}$ awareness of the threat posed to their existence, helplessness, dependence on others and the related shame, with incurable disease and physical disability. Their vulnerability consists not only in loss of health and self-sufficiency, but also in violation of identity (of the idea "who I am"), in loss of self-respect and value. ${ }^{26}$ It is therefore imperative in the "impersonal" environment of social services to approach the clients in a way that fortifies their worth not only as human persons and individualities, but also as dialogical beings who realize themselves in relationships. To maintain these patients' satisfaction with life it is important to engage in open dialogical communication concerning their health and social problems, as confirmed by L. Lorefice and M. Vachová. ${ }^{27}$ Similarly S. E. Thorne shows that a

24 Cf. Jiří JANKOVSKÝ, Etika pro pomáhající profese, Praha: Triton, 2003, p. 130.

25 According to Recommendation of the Committee of ministers of the Council of Europe multiple sclerosis patients as chronically persons belong in a very vulnerable group in society - see (C) Council of Europe, Recommendation No R (98) 11 of the Committee of ministers to member states on the organisation of health care services for the chronically ill (on-line), at https://wcd.coe.int/com.instranet. InstraServlet?command $=$ com.instranet. $\mathrm{CmdBlobGet \& InstranetImage}=532282 \&$ SecMode $=1 \& D o c I d=485452 \& U$ sage $=2$, retrieved November 30, 2013.

26 Cf. Jaro KřIVOHLAVÝ, Psychologie nemoci, p. 131.

27 Cf. Lorena LOREFICE and others, What do multiple sclerosis patients and their caregivers perceive as unmet needs?, BMC Neurology 
relationship of trust and effective communication helps MS patients to accommodate better and cope with their disease. ${ }^{28}$ MS patients need their surroundings to acknowledge the position and education they have reached as well as the social merits they have deserved. ${ }^{29}$

According to H. Francová's research many MS patients have been led by their disease to reappraise their life priorities and become aware of fundamental attitude values, such as: help (in the sense of psychological support), sympathy and love (of partner). ${ }^{30}$ At the same time they have become more sensitive, more attentive to their surroundings and have ceased to be focused on themselves. ${ }^{31}$ My survey of MS patients in various parts of the Czech Republic (2012) confirms H. Francová's research. They state that the most important value in life are interpersonal relationships, love and communication with their nearest ones (family, friends), etc. The second most important value has naturally turned out to be own health (keep one's health, re-gain health, be active, self-sufficient, not suffer pain etc.), the third value the respondents state are their predilections (my cat), basic needs (eat and sleep well; peace and well-being) or spiritual matters (the belief that everything has a meaning; faith). ${ }^{32}$

As dialogical and social beings persons with multiple sclerosis naturally need to relate to others, live for other and love someone. ${ }^{33}$ But in their vulnerability they also need to experience love, attention and deeply human understanding and to be accepted by others as they are, otherwise they suffer. A psychologically adequate attitude to a patient appraising her natural dignity fortifies mutual trust, friendship, belonging, and brings a certain sense of satisfaction and security to both parties in the communication. The caregivers ought to not only reflect the patients' loss of self-sufficiency, health and social ties, but also accept them as equal partners in dialogue, protect them from doubts concerning their worth and raise them to a maximally full-valued and as far as possible autonomous life with the disease. When accompanying the patient, however difficult it may be, her disease may be reflected positively as a challenge or chance to live one's life in a more worthwhile way. ${ }^{34}$

In the issue of proper attitude values towards MS patients one can utilize the conception of basic anthropological needs, as laid out in the generally known hierarchy of human needs by the American psychologist A. H. Maslow. ${ }^{35}$ According to him, the most basic are physiological needs, then comes the need of security, further the need of love and belonging, then the need of appreciation and respect, and finally the need of self-realization.

\footnotetext{
13:177, 2013, p. 4; Marta VACHOVÁ, Sociální aspekty roztroušené sklerózy, p. 454.

28 Cf. Sally E. THORNE and others, The context of health care communication in chronic illness, Patient Education and Counseling $54 / 2004$, p. 299.

29 From personal experience in social work with MS patients.

30 Cf. Hana FRANCOVÁ, Psychosociální aspekty nemocných roztroušenou sklerózou, KONTAKT - odborný a vědecký èasopis pro zdravotní sociální otázky no. 3-4, 2005, p. 289.

31 Cf. ibid., p. 288.

32 Based on the results of my questionnaire survey of 120 multiple sclerosis patients in the Czech Republic, primarily aimed at determining the approach such patients expect in the environment of social services, 2012. Below I present more detailed results of the part aimed at determining the most important values. Some respondents answered the question with two most preferred values (e.g. family and health), which is why adding up the percentages does not yield $100 \%$. Of the 120 respondents $63(52.5 \%)$ answered that the most important values in their lives are interpersonal relationships, love, and communication with their nearest (family, friends), etc. For 60 respondents ( $50 \%)$ the most important value is own health (maintain health, regain health, be active, be self-sufficient, not suffer pain, etc.). The remaining 6 respondents $(5 \%)$ stated the most important value in their lives to be their inclinations, basic needs, or spiritual matters (eat and sleep well, peace and wellbeing, my cat, belief that everything has a meaning, faith).

33 Cf. JOHN PAUL II., encyclical Redemptor hominis, 10 (furher only RH and section number); Walter KASPER, Láska jako smysl bytí, Teologické texty 2/2010, p. 57; Joseph RATZINGER, Concerning the Notion of Person in Theology, Communio: International Catholic Review 3/1990, p. 439.

34 Cf. Jiří JANKOVSKÝ, Etika pro pomáhajicí profese, pp. 128-130.

35 Cf. Abraham Harold MASLOW, A theory of human motivation, Psychological Review 4/1943, 372-385.
} 
An outstanding proponent of an approach appreciating the dignity of human beings was the American psychologist and psychotherapist C. R. Rogers, who in his "person-centered approach" considered the following attitude values to be very important in communication with clients: acceptance (unconditional acceptance of the other), empathy (putting oneself in the place of the other) and authenticity (sincerity to the other). ${ }^{36}$

The psychologist K. Kopřiva in his book Human Relationship As Part of Profession (2006) presents the results of a questionnaire survey for nurses and social workers in homes for the elderly (some multiple sclerosis patients are already elderly - author's note). It deals with the expected preferred capabilities of nurses and attendants if some of their near ones came to stay in a home for the elderly. The survey results have shown that the assisting professionals themselves would first of all expect affection (kindness, willingness, love, and others), then patience (also tranquility, composure, and others), empathy (also appreciation, sympathy, and others), and only in the fourth place expertise (also professionalism, knowledge, and others). On this the author notes that the atmosphere created by the assisting professional in interacting with the client can support the client, but it can also discourage her. "The client needs to trust (the assisting professional), feel secure and accepted. Without this relational framework the assisting professional's work is nothing but exercising entrusted power." ${ }^{37}$ In my research in social services I learned that MS clients most value the caregivers' sincerity, then trust, kindness, ability to understand the other (empathy), ability to respect, esteem others, be interested in the other and her needs, they also positively value willingness to help, ability to apologize, want good for the other, forgive, be grateful. ${ }^{38}$

In order to understand the reasons of the human being's personal dignity, which is not determined by her health condition, it is necessary to elucidate the theological dimension of being human. In the Judeo-Christian tradition the value of the human person derives from theology of creation, which gives human beings high standing in God's plan of creation. In the order of creation the human being is elected to be an image of God, to have a spiritual immortal soul and to be called to eternal life in communion with God. ${ }^{39}$ As divine image human beings have a natural desire for God imprinted in their hearts - i.e., a desire for fulfilled and happy life, for freedom, truth, beauty, the good, and love. ${ }^{40}$ Only in relationship with God does human life have meaning, its divine worth and fulfillment. ${ }^{41}$ That is why every human person ultimately deserves to be treated in a way worthy of God. ${ }^{42}$ If a human being undergoes suffering, pain,

\footnotetext{
36 Cf. Carl ROGERS, Client-centered therapy: Its current practice, implications and theory, London: Constable, 1951, pp. 363 and 432; Carl ROGERS, The necessary and sufficient conditions of therapeutic personality change, Journal of Consulting Psychology 2/1957, pp. 97-99.

37 So far Karel KOPŘIVA, Lidský vztah jako součást profese, Praha: Portál, 2006, p. 15.

38 Based on the results of my questionnaire survey of 120 multiple sclerosis patients in the Czech Republic aimed at determining the approach such patients expect in the environment of social services. The list of individual expected qualities in approach was drawn from the psychological literature of J. Křivohlavý, leading Czech expert in social communication in assisting professions (Jaro KŘIVOHLAVÝ, Já a Ty - O zdravých vztazích mezi lidmi, 2. ed., Praha: Avicenum, 1986, pp. 131-209; Jaro KŘIVOHLAVÝ, Vážně nemocný mezi námi, Praha: Avicenum, 1989, pp. 75-76; Jaro KŘIVOHLAVÝ, Povídej - naslouchám, 2 ed., Kostelní Vydří: Karmelitánské nakladatelství, 2010, pp. 60-99). The Christian attitude values needed for accompanying ill persons were drawn from the work of John Paul II. (JOHN PAUL II., apostolic letter Salvifici doloris, 28 [further only SD and section number]), Benedict XVI. (BENEDICT XVI., encyclical Deus caritas est, 31[further only DCE and section number]), Karl-Heinz Peschke (Karl-Heinz PESCHKE, Křestáaská etika, 2. ed., Praha: Zvon, 2004, pp. 187, 190-207), and Aleš Opatrný (Aleš OPATRNÝ, Pastorační péče v méně obvyklých situacích, Praha: Pastorační středisko Praha, 2005, pp. 76-79). The survey has shown the following most valued attitude capabilities of caregivers, listed in order of mean evaluation on a 1-5 scale from the most preferred ones to ones less expected: 1. sincerity (1.13); 2. trust (1.23); 3. kindness (1.35); 4. having understanding for the other, empathy (1.36); 5 . respecting the other (1.37); 6. interest in the other and her needs, willingness to help (1.38); 7. being able to apologize (1.39); 8. wishing good for the other (1.41); 9. being able to forgive (1.46); 10 . being grateful (1.55).

39 Cf. SECOND VATICAN COUNCIL, constitution Gaudium et spes, 19 (further only GS and section number).

40 Cf. GS 17-19; Catechism of the Catholic Church, Praha: Zvon, 1995, 27 and 33 (further only CCC and section number).

41 Cf. GS 2; BENEDIKT XVI., encyclical Caritas in veritate, 78 (further only CIV and section number).

42 Cf. Karl-Heinz PESCHKE, Křestáanská etika, p. 305.
} 


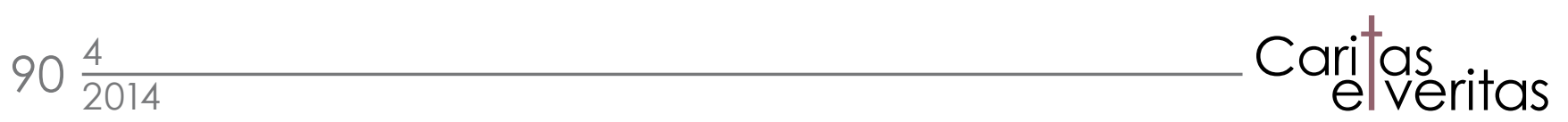

or disease, she loses none of her dignity, although she suffers from a certain evil. ${ }^{43}$ As divine image human beings are called to become ever more like their Creator. ${ }^{44}$ They can only fully achieve that in the power of God's Spirit by showing selfless love to others. ${ }^{45}$ The greatest exemplar of such acting is the incarnate Son of God in Jesus Christ (Jn 15:12), who is the true image of God (2 Cor 4:4; Col 1:15; Heb 1:3). By becoming like the Son of God human beings participate in divine Sonship. From the Christian point of view the adequate approach to MS patients is therefore based on the ethos of Jesus of Nazareth. Thus motivated approach raises the patient to the true dignity of a son of God. ${ }^{46}$

As mentioned above, from the theological point of view the human being fulfills her mission on earth by manifesting love for others according to the example of Christ. In him divine love, caritas, which freely loves others regardless of their bodily or spiritual attractiveness, was revealed to humanity. ${ }^{47}$ God's caritas is a love which bows down to all those in need. ${ }^{48}$ We can find an illustrative biblical example of such love in Christ's likeness of the merciful Samaritan (Lk 10:25-37). The story can inspire caregivers in social services to so-called samaritan attitude, ${ }^{49}$ i.e., having a heart sensitive to the suffering of others, approaching those in need and helping them as possible. ${ }^{50}$

True human greatness is thus revealed in the quality of relationship to those who suffer and their needs. ${ }^{51}$ When the suffering of a human being in need is shared, the sufferer is permeated by the light of love. She is no longer alone and by the comfort extended to her experiences the community of con-solatio in her solitude. ${ }^{52}$ The caregiver is thereby likened to God's Son who liberates humans from solitude. ${ }^{53}$

Responsible care of the ill in the Christian tradition relies to a great extent on Christ's parable of the last judgment in the Gospel of Mathew (Mt 25:31-46). Proper personal attitude to all in need, with whom Christ identifies, is shown as an important criterion of salvation. Jesus himself tells his disciples to imitate his love (Jn 15:12) and promises the merciful that they will receive mercy (Mt 5:7).

The theological positions described above comprise concrete aspects that may be taken into account and applied in approaching MS patients in social services. There are also other moments that may not be left aside.

As any long-term disease, multiple sclerosis may lead the patients to close in on themselves, to doubt their inner security, and thereby to raise existential and spiritual questions. ${ }^{54}$ As a

\footnotetext{
43 Cf. SD 7.

44 Cf. Ctirad Václav POSPíŠIL, Ježíš z Nazareta, Pán a Spasitel, 4. ed., Praha: Krystal OP; Kostelní Vydří: Karmelitánské nakladatelství, 2010, p. 424. 45 The theological expression "creation of humans in divine image" is relevant for the quality of relationship to others, since according to the Hebrew tradition to be an image of God means to imitate the character of God, who by his essence is absolute Love (1 Jn 4:16) - cf. DCE; Jan HELLER, Hlubinné vrty, Praha: Kalich, 2008, p. 241. According to the divine commandment of love, a human being ought to first of all love God with all her being (Dt 6:5; Dt 11:13; Mt 22:36-38; Mk 12:30; Lk 10:27) and then love one's neighbor as oneself (Lv 19:18; Mt 22:39; Mk 12:31; Lk 10:27).

46 So far cf. Ctirad Václav POSPíŠIL, Ježíš z Nazareta, Pán a Spasitel.

47 Cf. ibid., pp. $426-427$.

48 Cf. ibid., p. 426.

49 So far cf. SD 30.

50 Cf. SD 28.

51 Cf. RH 10; CIV 1; BENEDICT XVI., encyclical Spe salvi, 38.

52 Cf. ibid.

53 Cf. Ctirad Václav POSPÍŠIL, Ježíš z Nazareta, Pán a Spasitel, p. 426.

54 Cf. Aleš OPATRNÝ, Nemocní, in: Praktická teologie pro sociální pracovníky, ed. Michael MARTINEK, Praha: Jabok, 2008, pp. 140-141.
} 
result of their disease, people suffering from MS sometimes undergo a deep revision of their relationship to God or otherwise perceived absolute being. Those who believe in a personal God frequently feel that the Almighty is punishing them and that they have not deserved such punishment. That is why some conclude in their despair that they are being punished for sins committed in previous lives and turn from faith in God to belief in fate, which vicariously helps them to accept their incomprehensible lot and cope with the disease. ${ }^{55}$ But when patients accept their suffering as a vocation and spiritually unite themselves to the cross of Christ, they can live it as participation in the salutary work of God (1 Pt 4:13; Col 1:24). ${ }^{56}$ The reality of the disease can therefore be perceived in a positive sense as God's grace, as a chance to live one's life in a more worthwhile way. ${ }^{57}$ When the incurably ill revise their inner self in depth, their heart is converted. ${ }^{58}$ They then appreciate an attitude of their surroundings which liberates them from threatening feelings: loss of worth and dignity, despair, solitude, insecurity, or fear of death. In the social services environment such clients are grateful for every expression of real friendship, acceptance, listening and mutuality, since such receiving community helps them to experience a sense of home and security. ${ }^{59}$ A social service establishment applying divine caritas in the approach to clients can theologically be viewed as a place of meeting God, a place where patients can feel at "Home". By approaching MS patients in a way that appreciates the spiritual dimension of a human being, the caregivers can to a certain extent spiritually accompany their clients.

To summarize we can state that an approach appraising the dignity of MS patients, as well as ultimately the dignity of God, in the assisting professions is manifested by the following: respect for the other, trust, sincerity, the samaritan attitude (interest in the patient and her needs, including providing care), wishing good for the other (benevolence), having understanding for her (empathy), being kind, being able to apologize, to forgive, to be grateful. ${ }^{60}$ The adequate attitude to MS patients aims (as far as possible) to promote their dignity, inner integrity, social

55 Based on the results of my questionnaire survey of 120 multiple sclerosis patients in the Czech Republic aimed at determining the approach such patients expect in the environment of social services, 2012; further cf. Eva HAVRDOVÁ - Martina HOSKOVCOVÁ - Jana DUŠÁNKOVÁ - Eva KRASULOVÁ - Martina PURŠOVÁ, Je roztroušená skleróza váš problém?, p. 153.

56 Cf. SD 26, 30. In the conception of theology of the cross the meaning of sharing in Christ's salutary suffering consists in participation in the mystery of redemption and salvation and in the mystery of God's self-revelation - cf. Ctirad Václav POSPÍŠIL, Teologie služby, Kostelní Vydř́: Karmelitánské nakladatelství, 2002, p. 184.

57 Cf. Jiří JANKOVSKÝ, Etika pro pomáhající profese, pp. 128-130. Serious illness, suffering, or disability can be perceived as a vocation: to elicit love as a selfless gift of self to suffering people (cf. SD 29,30), to "provoke" prayer (cf. @ Radio Vaticana, Pravá radost utrpení neopomíjí, ale chápe ho - homily of Benedict XVI. (on-line), at http://www.radiovaticana.cz/clanek.php4?id=12412, retrieved December 22, 2013), to be teachers of humanity (cf. @ Vatican, Committee for the jubilee day of the community with people with disabilities. The person with disabilities: subject - active agent in ministry (on-line), at http://www.vatican.va/jubilee_2000/jubilevents/jub_disabled_20001203_scheda3_en.htm, retrieved December 22, 2013; Jean VANIER, Cesta k lidství, Praha: Portál, 2004, pp. 39-69.).

58 Cf. Ctirad Václav POSPÍŠIL, Ježíš z Nazareta, Pán a Spasitel, p. 426.

59 This is evident from two testimonies of MS patients I have recorded in practice. In the view of C. V. Pospíšil a MS patient can be seen as a suffering human being who longs to be accepted as a person, individual. She is in some way aware that something mysterious is happening in her. That is why she wants to be listened to, wants to be accepted, wants to be understood and refuses to be degraded to a number, a case, because she longs to have a name in our eyes - cf. Ctirad Václav POSPíŠIL, Teologie služby, p. 193. By openness of heart and sharing oneself with others a human being fulfills her existence in the world, discovers herself and becomes fully human, being in her essence a dialogical being - cf. Martin BUBER, Problém človéka, Kalich: Praha, 1997, p. 94; Martin BUBER, Já a Ty, Praha: Kalich, 2005, p. 44; Karel VRÁNA, Dialogický personalismus, Praha: Zvon, 1996, p. 11. In connection with an approach appraising human dignity Pope Benedict XVI. pointed out the Greek word katanoein, which means to note well, be attentive, look with awareness, observe a reality. In the contemporary world the expression challenges us to be attentive to others, take care of one another, to openness of the heart, brotherhood, solidarity, and justice cf. BENEDICT XVI., Intelekt srdce, Teologické texty, 4/2012, p. 169. In the encyclical Deus caritas est Benedict XVI. points out the necessary expert competency of assisting professionals in the context of the specific profile of charity works of the Church, which, however, is not sufficient. Those who suffer need humanity and an attentive heart. In charitable institutions of the Church it is not sufficient to do what is at present necessary; it is further necessary to pay attention to the ones in need according to inspiration of the heart, so that they may experience the richness of the humanity of the caregivers - so far cf. DCE 31.

60 Cf. DCE 31; SD 28 (according to Lk 10:29-37); Karl-Heinz PESCHKE, Křestáanská etika, pp. 187 and 190-207; Aleš OPATRNÝ, Pastorační péče v méně obvyklých situacích, pp. 76-79; Jaro KŘIVOHLAVÝ, Já a Ty - O zdravých vztazích mezi lidmi, pp. 131-209; Jaro Kर̌̃IVOHLAVÝ, Vážně nemocný mezi námi, pp. 75-76; Jaro KŘIVOHLAVÝ, Povídej - naslouchám, pp. 60-99. 
integration, own identity, autonomy, satisfaction, responsibility for themselves, as well as development (ripening) of personality.

\section{Conclusion}

Social services clients with multiple sclerosis are confronted with awareness of the incurability of the chronic form of the disease, with human vulnerability, helplessness and dependence on others, as well as ever graver disability. Awareness of the threat posed to their existence brings insecurity and worry. A part from early treatment and rehabilitation they need to experience proper psychosocial support from their nearest as well as professional caregivers. With reference to the holistic view of the human being as well as findings from social services clients with multiple sclerosis themselves we can state that caregivers' approach appraising the dignity of a human being with multiple sclerosis in social services is one that respects clients as equal partners, does not disable them, is not like approaching children, respects their speed, and is perceptive to their needs. If caregivers approach clients in a way that appraises human dignity, they boost the patients' motivation to live their life with the disease in a fuller way, and thus take care of the quality of their life in a more autonomous way.

\section{Approaching Clients With Multiple Sclerosis in Social Services}

Abstract The paper aims to reflect on multiple sclerosis, its social impact in the lives of patients, and ways of approaching such clients in social services. The author describes ethically problematic forms of approaching such clients occurring in social services. He then points out certain aspects that sustain a holistic perception of persons with multiple sclerosis, help appraise the complexity of their needs and rights, and can thus help improve the quality of practice.

Key words multiple sclerosis, social services, approach to patients, accompanying patients, quality of social services, meeting the needs of patients, persons with chronic diseases, persons with disabilities 